$12-12-2021$

\title{
How Important Is Physical Education for The State Conservatory of Uzbekistan Students' Successful Performing Activities
}

\author{
Munawara Abdullayeva \\ The State Conservatory of Uzbekistan,abdullaeva_15@hotmail.com \\ Shokhida Gafurova \\ The State Conservatory of Uzbekistan, shahida@yandex.ru
}

\begin{abstract}
Every musician's profession assumes regular hours-long practices, long-term music performance training and concert activities. The music profession is hard work that involves continuous rehearsals, followed by performances at concerts. This negatively affects the state of their health. This becomes the reason for the manifestation of occupational diseases and the termination of performing activities. Therefore, the formation of the physical well-being of a musician seems to be extremely important for successful and long-term performing activity. Consequently, it is relevant to introduce various types of physical culture into the daily routine of every musician starting from the early years and further into higher education. This paper gives insights into the issues of sport and physical education at the state conservatory of Uzbekistan. Today musicians become well informed through the internet, publications, seminars, and books on how sport can have a positive influence on musician's performance. The paper examines how to determine whether moderate-intensity activities can assist in playing an instrument and can be incorporated into the curriculum of the musical education for the benefit of the students- musicians.
\end{abstract}

Keywords:

musicians, conservatory, sport, physical education, physical health, performance, artistic activity, occupational diseases, physical culture.

\section{Recommended Citation}

Gafurova, S. and Abdullaeva, M. (2021) "How Important is Physical Education for The State Conservatory Of Uzbekistan Students' Successful Performing Activities”. Eurasian Music Science Journal. Tashkent, Uzbekistan, (2), pp. 44-53.

DOI: $10.52847 /$ EAMSJ/vol_2021_issue_2/68.

This Article is brought to you for free and open access. It has been accepted for inclusion in Eurasian music science journal (www.eamsj.uz). 
$12-12-2021$

The profession of musician requires a high degree of development of all components of a person's physical integrity and well-being. To ensure creative work, a musician needs special knowledge and skills to extract beautiful sounds from an instrument. He/she needs the ability to hear music and create it, to arrange, improvise, and possess a high technique of playing the instrument. Thus, being a musician is hard, almost round-the-clock work. It encompasses continuous rehearsals, self-improvement, the release of new works, practices in the morning, followed by performances in the evening. This takes away almost all the energy, weakens the person, and negatively affects the state of their health. No matter what instrument a musician plays, be it cello or violin, piano or accordion, he/she must be physically well fit.

Thus, the formation of the physical well-being of a musician, as the realization of his objective need for exercises that correct the physical condition, seems to be extremely important for successful and long-term performing activity. The key to the success of a musician's public activities is his psychological state and emotional readiness.

In this case, everything matters, be it physical qualities, somatic abilities, as well as fit, grace, posture, and ease of movement. The best way to achieve it is through regular physical training.

Today, responding to the challenges of the time, a large number of modern innovative technologies for teaching physical education are increasingly being developed and applied in the sphere of musicians training. Since in contemporary culture, one of the main noteworthy challenges is a significant decrease in the level of physical health of the young generation, aggravated by a decrease in interest in physical education among young people [1].

However, there is an opinion among musicians that hands and fingers are very sensitive and prone to injury if one engages in any vigorous physical activity. Cutting a lip for wind instrumentalists, hurting a foot for drummers or twisting a finger for 


\section{$12-12-2021$}

pianists are usual nightmares for the musicians, which are perfectly reasonable. Maria Kliegel argues, that musicians are scared to do sports because their teachers have always been frowned on combining music and sport. The students-musicians are often excused from sport activities, without realizing there are beneficial sides for them. However, she thinks that musicians on the contrary should be encouraged to try sport because sitting in the room repeating the same strenuous body motions for hours, weeks and decades, cannot be healthy or enjoyable.

She writes:

“...there's so much in sport that can be put back into music. You learn about reflexes, how to breathe, judge speed, anticipate, react. ... Playing sport helps you to get to know your body: how muscles, tendons and ligaments work, how to feel or create tension and relaxation, and how injuries heal. Many musicians don't know about these processes, which is why they are scared to face them" [2].

Liz Hinley, who earned her Bachelor of Arts degree in music, stressed that music and sport complement each other therefor it is beneficial for a musician. She further argues that sport can improve a musician's skills and performances. It can help taking their performances to the next level; may help to cope with stress such as performance anxiety, especially post-performance; can enhance and support posture and reduce musculoskeletal imbalances; as well as it can improve range of motion, blood flow, and fine muscle strength to aid in holding and controlling an instrument [3].

According to other authors, sport plays a pivotal role and is more beneficial than commonly thought since strength, endurance, and flexibility in particular have an immense influence on the musician's performance $[4,5]$.

For a successful musical career, a musician needs to acquire a state of optimal readiness for the concert when the body obeys and stress is much relieved. In other words, a good musician's physical health allows him to feel substantially fit. For 


\section{$12-12-2021$}

student musicians, various tests in the form of tests, exams, auditions also require maintaining good physical shape, particularly physical and psychological fitness.

It is well known that before a performance, musicians often experience excitement, which causes many negative phenomena, such as impaired coordination of movements, decreased tactile sensitivity, and even memory lapses. All these affect the quality of the performance, lead to low self-esteem and skepticism, and stage fright. However, even if the performer coped well and played the concert, after the performance, he/she needs a long time to normalize the excitement they got during the concert. Therefore, as Kon'kova argues, "Physical health and performance along with professional excellence are fundamental factors for successful musical performance" [6]. As a result of prolonged stay in a forced posture and low motor activity, disorders of the musculoskeletal system, osteochondrosis, flat feet, curvature of the body in the form of kyphosis, and scoliosis can occur. Kyphosis and right-sided scoliosis are most common in piano students, while left-sided scoliosis is more common in string and wind instruments [6].

Konovalov also states, that "Daily music lessons for several hours a day, a long period of playing without interruptions, many hours of learning a difficult repertoire lead to statistical stress and, accordingly, to health problems" [7]. Thus, he argues that physical activity and sports reduce the level of emotional arousal and thus help to cope with periods of crisis of creativity and peaks of artistic activity.

In this regard, musicians must develop techniques of psychological relaxation, proper breathing, gymnastics for prevention and corrections arising in connection with the musical performance of specific problem areas. Physical exercises can be implemented by a musician in the form of morning hygienic gymnastics, in pauses during specialty classes, in physical education classes, in organized physical culture and sports groups, independently or with the coach or trainer. The listed types of 


\section{$12-12-2021$}

classes solve the following tasks: functional training, development of physical qualities, and prevention of diseases, rehabilitation, and precautionary measures [8]. When performing long, tense, and intense musical pieces, a moment comes when its initial intensity cannot be maintained, that is, fatigue sets in. This functional state of the body is manifested in a temporary decrease in a working capacity. Fatigue causes the discoordination of functions in the central nervous system and disruption of metabolic processes in working muscles [6].

Ryazantzeva writes, that "Exercises in passing and catching the ball improve the function of vision. Playing with a ball (basketball, volleyball) not only minimizes the possibility of injury but also develops the strength and flexibility of the hand. The most accessible (from the point of view of safety and education of professionally important physical qualities of a musician) for musicians, he considers playing tennis, badminton, and table tennis" [9]. While Schmidt-Shklovskaya argued, that "For young people who decide to become highly professional musicians and study in schools and conservatories, health and low physical fitness become a brake on the improvement of the performing technique, which requires a certain degree of development of physical qualities and functions, and often lead to the occurrence of occupational diseases" [10]. Thus, some musician specialists note the need and great importance of physical exercises, both in the field of improving the performing technique and in the field of prevention and treatment of occupational diseases. Some of them recommend steadily developing and training muscles, engaging in winter and summer sports, rhythmic gymnastics, tennis, table tennis, badminton. Thus, physical culture and sports play an important role in the professional training of a musician and are the key to successful public activities. Guided by the modern strategy for the development of physical culture and sports [11] one of the priority directions of physical education and physical culture has been the search for new attractive forms of organizing educational and extracurricular activities, methods, and means that ensure health promotion and increase the level of physical fitness of 
$12-12-2021$

young Uzbekistan's people. As well as attracting them to regular, systematic physical education and sports.

It is worth noting here that many famous musicians have been involved in sports successfully, and this not only did not interfere but also helped in their careers.

Among them is Denis Matzuev, a pianist with enchanting techniques. Since childhood he has been playing football and hockey. Micheline Ostermeyer is a French athlete and concert pianist. Julius Katchen is an American concert pianist, possibly best known for his recordings of Johannes Brahms's solo piano works, was once ranked in the top few table tennis players in the U.S. Leon Bates is one of America's leading pianists. He is a sports enthusiast and a disciplined bodybuilder, which he feels aids his concentration and maintains his strength for the rigors of a performance career [12]. Tzimon Barto is an American classical pianist. He is also a bodybuilder [13].

A British cello soloist, chamber musician, recording artist Colin Carr stresses in his interview to The Strad:

"I used to have horrible lower back spasms, but now I do stretches and sit-ups every day to keep the back and stomach strong and flexible, which has made a big difference. And now I am an obsessive runner. I've enjoyed running for more than 30 years, but over the last two years or so it has become an addiction" [14].

Obviously, one has to select the kinds of sports. Nevertheless, playing sports cannot harm anyone if it treated correctly without excessive fanaticism. While "professional sports» may not be necessary, physical education, where there is no rigid schedule of loads, undoubtedly beneficial for musicians. The most accessible are tennis, badminton, and table tennis.

To become good professionals and performers, students of the State Conservatory of Uzbekistan need about 20 years of continuous music education. The current state of physical education at the State Conservatory of Uzbekistan does not meet the goals and objectives of educating a versatile musician performer. The 


\section{$12-12-2021$}

organization and the curriculum of the physical education at the institute provide inadequate approach to this category of students. Since the conservatory does not provide for a scientifically grounded system that meets modern requirements for a harmoniously developed personality, capable of fully realizing his abilities. First of all, it is necessary to determine the organizational conditions to optimize the process of physical education of students and musicians. Observation and analysis of the existing practice of organizing physical education at the conservatory revealed its ineffectiveness. Students showed their reluctance to take physical education classes. Some because of lack of time but others because they heartily believed that sports and the profession of a musician are not compatible. When organizing physical education, it is necessary to take into account the specifics of the professional activity of the student contingent.

In this regard, attempts have been taking at the Conservatory of Uzbekistan to develop various areas of education in such a way that it would fully satisfy the needs of students in physical activity, taking into account their personal preferences. Moreover, physical activity should be considered following the physical fitness and individual characteristics of students.

The main task of the authority of the conservatory is to teach young musicians to recognize the emerging problems in time and be able to prevent them. Table tennis, aerobics, and gymnastics sections have been organized by the sports club "Composer" at the State Conservatory of Uzbekistan, where students are invited to join classes for free.

Considering that the structure of physical activities should include the systematic use of a wide range of physical education means, the conservatory is working to ensure that physical education is professionally oriented. The effectiveness of physical education should be consistent with the specifics of the professional activity of studying musicians, their value orientations, motives, and needs. 
Therefore, traumatic sports are exception for musicians especially for pianists, string players, etc., because for them hands are a particularly valuable part of the body. During polling students of the $2 \mathrm{nd}$ and 3rd years of the Conservatory, opinions on whether students need to go in for sports were divided. Many students said that tennis was traumatic. However, some said that when playing tennis, the arms become stronger and less tired. Other muscles are also included in the work of the muscles that participate in playing the instrument during sports, which allows the entire muscular-ligamentous apparatus to develop harmoniously.

Physical training is a process aimed at the formation, development, and improvement of motor abilities, increasing the functional capabilities for the activity of students in studies and future professions. Good physical fitness will allow musicians to feel a balanced and well-tuned body.

It is also essential to teach the general theoretical foundations to students, which will allow them to understand fully the processes occurring with the body of a person who regularly goes in for sports. Knowledge of the theoretical foundations will provide an integrated approach to the professional training of specialists and will lead to high-quality and successful performing activities of future musicians.

The construction of the process of physical education at the Conservatory of Uzbekistan should be carried out based on year-round adaptation to the peculiarities of the professional activity of students to solve specific problems of physical education aimed at improving the quality of professional training. Building a system of the year-round physical education process according to the principle of system will allow solving operational and long-term tasks.

A few words should be said about the physical education teacher, who must have a set of competencies to form students' stable motivation for physical education. The teacher must be able to integrate physical education into professional music education, taking into account the specifics of professional activity in a music university. The physical training teacher must prepare and organize the educational 


\section{$12-12-2021$}

process, taking into account the negative attitude of musicians to sports. The teacher needs to offer such activities to the students so that the latter develop the proper perspective to sports activities and a need to work out regularly. This should reflect the feedback of the physical and professional fitness of students. The state of the performing apparatus depends on the degree of physical fitness, expressed in the mental and functional preparedness of future specialists, their physical performance.

To conclude it should be said that any professional musician could do sports and be a musician. To be on the safe side one should stick to safer sports, wear protective clothing and use common sense to avoid sprains, twists, and broken bones. In order to endure the highly demanding physical requirements of playing a musical instrument for hours every day one should do physical exercises to make the body stronger and more flexible, because only that way one can make it more resilient.

\section{References:}

[1] Devyatkina, A. (2015). Povyshenie kachestva zanyatiy po fizicheskoy culture v vuze posredstvom muzykalnogo soprovojdeniya [Improving the quality of physical culture lessons at the university by means of musical accompaniment]. Molodoy Uchenyi [Young Scientist]. No. 11.1 (91.1). pp. 75-77. Retrieved from https://moluch.ru/archive/91/19369/ (date accessed: 10/29/20212).

[2] Klieg, M. (2019). Classical musicians should play more sports. Retrieved form https://www.thestrad.com/debate/classical-musicians-should-play-moresports/1595.article.

[3] Hinley, L. (2018). Music and Sports: Why Do Both? Retrieved from https://www.alfred.com/blog/music-and-sports-why-do-both/. 
$12-12-2021$

[4] Wilke, C., Priebus, J., Biallas, B., \& Frobose, I. (2011). Motor activity as a way of preventing musculoskeletal problems in string musicians. Medical Problems of Performing Artists, 24-29. DOI:10.21091/mppa.2011.1003. Retrieved from https://www.researchgate.net/publication/50868570.

[5] Wasley, D., Taylor, A., Backx, K., \& Williamon, A. (2012). Influence of fitness and physical activity on cardiovascular reactivity to musical performance. IOS Press, 27-32. Retrieved from https://pubmed.ncbi.nlm.nih.gov/22246300/.

[6] Kon'kova, I.P. (2019). Fizicheskaya kultura muzykanta [Physical culture of a musician]. Molodoy Uchenyi [Young Scientist]. No 50 (288), pp. 458-460. Retrieved from https://moluch.ru/archive/288/65365/ (date accessed: 10/29/2021.

[7] Konovalov, I. (2011). Professionalno orientirovannoe fizicheskoe vospitanie studentov srednih spetzialnyh uchebnyh zavedeniy muzykalnogo profilya [Professional-oriented physical education of students of secondary specialized educational institutions of a musical profile]. Vestnik Baltiyskogo Federalnogo Universiteta im. I. Kanta. Seriya: Filologiya, pedagogika, psihologiya [Bulletin of the Baltic Federal University. I. Kant. Series: Philology, Pedagogy, Psychology]. No. 4. Retrieved form https://moluch.ru/archive/288/65365/.

[8] Galichaev, M. (2010). Zdorovie i fizicheskaya kultura musykanta: uchebnoe posobie [Health and physical culture of a musician: a tutorial] 2nd ed. Rostov: RGK after S.V. Rachmaninov.

[9] Ryazantzeva, A. (2011). Fizicheskaya kultura kak odno iz sredstv profilaktiki professinalnyh zabolevaniy muzykantov [Physical culture as one of the means of preventing occupational diseases of musicians] Selected Questions of Modern $\begin{array}{llll}\text { Science. } & \text { Part } & \text { Retrieved }\end{array}$ https://ozlib.com/1053335/iskusstvo/fizicheskaya_kultura_odno_sredstv_profilakti ki professionalnyh zabolevaniy muzykantov\#976. 


\section{Eurasian music science journal}

2021 Number 2 2021/2

\section{$12-12-2021$}

[10] Schmidt-Shklovskaya, A. (1971). O vospitanii pianisticheskih navykov [On the education of pianistic skills.] Leningrad: Publishing house "Music" Leningrad branch. p. 67. Retrieved from http://nauka-pedagogika.com/pedagogika-13-0004/dissertaciya-professionalno-prikladnaya-fizicheskaya-podgotovka-studentovmuzykalnyh-vuzov-ispolniteley-na-duhovyh-instrumentah\#ixzz7BAcg19Ms).

[11] Decree of the President of the Republic of Uzbekistan (2020) on measures for the widespread introduction of a healthy lifestyle and the further development of mass sports as one of the priority areas of physical education and physical culture dated October 30, 2020, No. UP-6099 URL: https://lex.uz/docs/5077669.

[12] Retrieved from https://rilearts.com/pianists/leon-bates/leon-bates-biography.

[13] Retrieved from https://www.washingtonpost.com/lifestyle/style/tzimon-bartoan-unconventional-pianist-philosopher-reformed-drugaddict/2011/01/13/AB9euWR_story.html).

[14] How breaking a thumb saved cellist Colin Carr's career. (2019). The Strad. Retrieved from https://www.thestrad.com/playing/how-breaking-a-thumb-savedcellist-colin-carrs-career/2859.article).

This Article is brought to you for free and open access. It has been accepted for inclusion in Eurasian music science journal (www.eamsj.uz). 